www.mdpi.com/journal/molecules

Article

\title{
Antifungal Activity of the Essential Oil of Illicium verum Fruit and Its Main Component trans-Anethole
}

\author{
Yongfu Huang ${ }^{1}$, Jianglin Zhao ${ }^{1}$, Ligang Zhou ${ }^{1}{ }^{1}$, Jihua Wang ${ }^{1}$, Youwen Gong ${ }^{1}$, Xujun Chen ${ }^{1}$, \\ Zejian Guo $^{1}$, Qi Wang ${ }^{1}$ and Weibo Jiang ${ }^{2}$ \\ 1 College of Agronomy and Biotechnology, China Agricultural University, Beijing 100193, China \\ 2 College of Food Science and Nutritional Engineering, China Agricultural University, Beijing \\ 100083, China \\ * Author to whom correspondence should be addressed; E-Mail: lgzhou@cau.edu.cn; \\ Tel.: +861062731199.
}

Received: 14 October 2010; in revised form: 20 October 2010 / Accepted: 25 October 2010 / Published: 27 October 2010

\begin{abstract}
In order to identify natural products for plant disease control, the essential oil of star anise (Illicium verum Hook. f.) fruit was investigated for its antifungal activity on plant pathogenic fungi. The fruit essential oil obtained by hydro-distillation was analyzed for its chemical composition by gas chromatography (GC) and gas chromatography-mass spectrometry (GC-MS). trans-Anethole (89.5\%), 2-(1-cyclopentenyl)-furan (0.9\%) and cisanethole $(0.7 \%)$ were found to be the main components among 22 identified compounds, which accounted for $94.6 \%$ of the total oil. The antifungal activity of the oil and its main component trans-anethole against plant pathogenic fungi were determined. Both the essential oil and trans-anethole exhibited strong inhibitory effect against all test fungi indicating that most of the observed antifungal properties was due to the presence of transanethole in the oil, which could be developed as natural fungicides for plant disease control in fruit and vegetable preservation.
\end{abstract}

Keywords: Illiciaceae; Illicium verum; essential oil; trans-anethole; antifungal activity, plant pathogenic fungi 


\section{Introduction}

Plant diseases are usually caused by plant pathogens including fungi, nematodes, bacteria, and viruses, among which fungi are the main pathogens, causing great yield losses in numerous important crops [1,2]. Over several decades, synthetic chemicals were always the chief means of preventing and controlling plant diseases, as they were effective, dependable and economic. However, abuse of synthetic agrochemicals has resulted in many problems, such as fungicide-resistance development of the pathogens [3], damage to the environment and human health, and ecosystem disruption [4]. So alternatives which are biodegradable, low-toxic and more effective, are in high demand. Research on natural products, which might substitute for synthetic fungicides or contribute to the development of new agents for plant disease control, has attracted much attention of investigators [5-10]. Plant essential oils are not only used as fragrance and flavouring agents in the food and beverages industries [11], but also may provide potential alternatives for use as plant fungal pathogenic control agents $[12,13]$ as a large number of plant essential oils have been reported to have antifungal activities [14-18].

Illicium verum Hook. f. (Illiciaceae), a medium-sized evergreen plant named star anise, is mainly distributed in the tropical and subtropical zones of Asia. The fruits are frequently used as a well known spice in the food industry, and were also used for treatment of stomach aches and sepsis in eastern Asian traditional medicine $[19,20]$. The main component in I. verum essential oil was identified as trans-anethole [21]. The previous investigations suggested that I. verum essential oil had insecticidal, antimicrobial and antioxidative properties [21-24]. To the best of our knowledge, there have been no detailed studies on the use of $I$. verum essential oil and its main component trans-anethole against plant pathogenic fungi, besides a few reports on the antifungal activity screening of the oil [21,23]. We report here the antifungal activity of $I$. verum essential oil and trans-anethole against plant pathogenic fungi in order to provide additional data in supporting of their utilization and development as fungicides for plant disease control.

\section{Results and Discussion}

\subsection{Essential oil analysis}

Quantitative and qualitative analytical results of the fruit essential oil of $I$. verum by GC and GCMS are shown in Table 1. Twenty-two compounds were identified, representing $94.6 \%$ of the whole composition of the oil. The most abundant component was trans-anethole (89.5\%). Other main components included 2-(1-cyclopentenyl)-furan $(0.9 \%)$ and cis-anethole $(0.7 \%)$. Our result identifying the main component as trans-anethole is similar to the previous reports though other components were different from each other [17,21]. The reasons for this phenomenon may be different geographical environments, growth seasons and physiological age of the plant, in addition to the method of oil preparation $[25,26]$. 
Table 1. Chemical composition of the essential oil from the fruits of I. verum.

\begin{tabular}{lcc}
\hline Compound $^{\mathbf{a}}$ & $\mathbf{R I}^{\mathbf{b}}$ & $\mathbf{R A ~ ( \% ) ^ { \mathbf { c } }}$ \\
\hline Camphene & 950 & 0.2 \\
$\beta$-Myrcene & 991 & 0.1 \\
$\alpha$-Phellandrene & 1003 & 0.1 \\
$\delta$-3-Carene & 1016 & 0.3 \\
$p$-Cymene & 1029 & 0.1 \\
Limonene & 1033 & 0.4 \\
trans-Ocimene & 1040 & 0.1 \\
$\gamma$-Terpinene & 1060 & 0.1 \\
Terpinolene & 1100 & 0.1 \\
Linalool & 1114 & 0.3 \\
Terpinen-4-ol & 1177 & 0.2 \\
Isobornyl thiocyanoacetate & 1203 & 0.4 \\
$\gamma$-Terpineol & 1198 & 0.4 \\
cis-Anethole & 1254 & 0.7 \\
trans-Anethole & 1387 & 89.5 \\
$\beta$-Elemene & 1389 & 0.1 \\
Cyperene & 1398 & 0.2 \\
$\beta$-Caryophyllene & 1418 & 0.1 \\
$\alpha$-Caryophyllene & 1450 & 0.1 \\
(+)-9-Epiledene & 1507 & 0.1 \\
Cubebene & 1672 & 0.1 \\
2-(1-cyclopentenyl)-Furan & 1694 & 0.9 \\
Total identified & & 94.6 \\
Monoterpene hydrocarbons & & 1.5 \\
Oxygenated monoterpenes & & 1.3 \\
Sesquiterpene hydrocarbons & & 0.4 \\
\hline
\end{tabular}

${ }^{\mathrm{a}}$ : The identified constituents are listed in their order of elution. ${ }^{\mathrm{b}}: \mathrm{RI}$ indicates the retention indices calculated against $\mathrm{C}_{8}-\mathrm{C}_{40} n$-alkanes on the HP-5MS column. ${ }^{\mathrm{c}}$ : RA indicates relative amount (peak area relative to the total peak area).

\subsection{Antifungal activity by direct contact assay}

The $\mathrm{IC}_{50}$ values of the oil and trans-anethole against mycelar growth of eleven plant pathogenic fungi are shown in Table 2. The essential oil had an obvious inhibitory activity against all test fungi, and the $\mathrm{IC}_{50}$ values ranged from $0.07 \mathrm{mg} / \mathrm{mL}$ to $0.25 \mathrm{mg} / \mathrm{mL}$. This indicated that the oil had a broad spectrum of activity against all tested plant pathogenic fungi. Among them, A. solani, B. maydis, $F$. graminearum, $P$. aphanidermatum and $R$. solani were the relatively sensitive fungi with their $\mathrm{IC}_{50}$ values as $0.09 \mathrm{mg} / \mathrm{mL}, 0.07 \mathrm{mg} / \mathrm{mL}, 0.08 \mathrm{mg} / \mathrm{mL}, 0.09 \mathrm{mg} / \mathrm{mL}$ and $0.08 \mathrm{mg} / \mathrm{mL}$, respectively. The positive control procymidone or carbendazim at $5 \mu \mathrm{g} / \mathrm{mL}$ completely inhibited the growth of all test fungi.

trans-Anethole, the dominant component in I. verum oil, has also been found in other plant essential oils [27-29]. It has been shown to possess insecticidal, larvicidal, and antimicrobial activities [30-32]. In order to compare the antifungal activity of trans-anethole with that of $I$. verum essential oil, transanethole was detected to display similar inhibitory activity on the test fungi with $\mathrm{IC}_{50}$ values closed to those of the oil (Table 2), which suggested that trans-anethole was a major contributor to the antifungal properties of $I$. verum essential oil. 
Table 2. Antifungal activity $\left(\mathrm{IC}_{50}\right)$ of $I$. verum fruit oil and trans-anethole against plant pathogenic fungi.

\begin{tabular}{|c|c|c|}
\hline Fungus & $\begin{array}{c}\text { Fruit oil } \\
\text { IC }_{50}(\mathrm{mg} / \mathrm{mL})\end{array}$ & $\begin{array}{l}\text { trans-Anethole } \\
\text { IC }_{50}(\mathrm{mg} / \mathrm{mL})\end{array}$ \\
\hline Alternaria solani & 0.09 & 0.11 \\
\hline Bipolaris maydis & 0.07 & 0.06 \\
\hline Botryodiplodia theobromae & 0.11 & 0.09 \\
\hline Fusarium graminearum & 0.08 & 0.10 \\
\hline Fusarium oxysporum f. sp. cucumerinum & 0.16 & 0.17 \\
\hline Fusarium oxysporum f. sp. lycopersici & 0.14 & 0.14 \\
\hline Fusarium oxysporum f. sp. vasinfectum & 0.25 & 0.20 \\
\hline Magnaporthe oryzae & 0.22 & 0.25 \\
\hline Pythium aphanidermatum & 0.09 & 0.07 \\
\hline Rhizoctonia cerealis & 0.10 & 0.11 \\
\hline Rhizoctonia solani & 0.08 & 0.07 \\
\hline
\end{tabular}

\subsection{Antifungal activity by vapor contact assay}

Two post-harvest pathogens, P. aphanidermatum and B. theobromae, were selected to evaluate the antifungal activity of the vapor components in I. verum essential oil as well as trans-anethole. Four days after exposure, the volatile components diffusing from the medium containing $0.5 \mathrm{mg} / \mathrm{mL}$ of $I$. verum essential oil inhibited the growth of $P$. aphanidermatum mycelia at a rate of $93.82 \%$, and transanethole at the same concentration in medium more greatly inhibited the mycelia growth (Figure 1). Their $\mathrm{IC}_{50}$ values were determined as $0.23 \mathrm{mg} / \mathrm{mL}(Y=4.386 X+7.838, R=0.989$, where $Y$ is the inhibitory probit value, $X$ is concentration logarithm of the sample in the medium, and $R$ is correlation coefficient $)$ for the oil, and $0.20 \mathrm{mg} / \mathrm{mL}(Y=4.045 X+7.799, R=0.983)$ for trans-anethole, respectively.

Figure 1. Effect of vapor components in I. verum fruit oil and trans-anethole on mycelial growth of $P$. aphanidermatum by vapor contact assay.

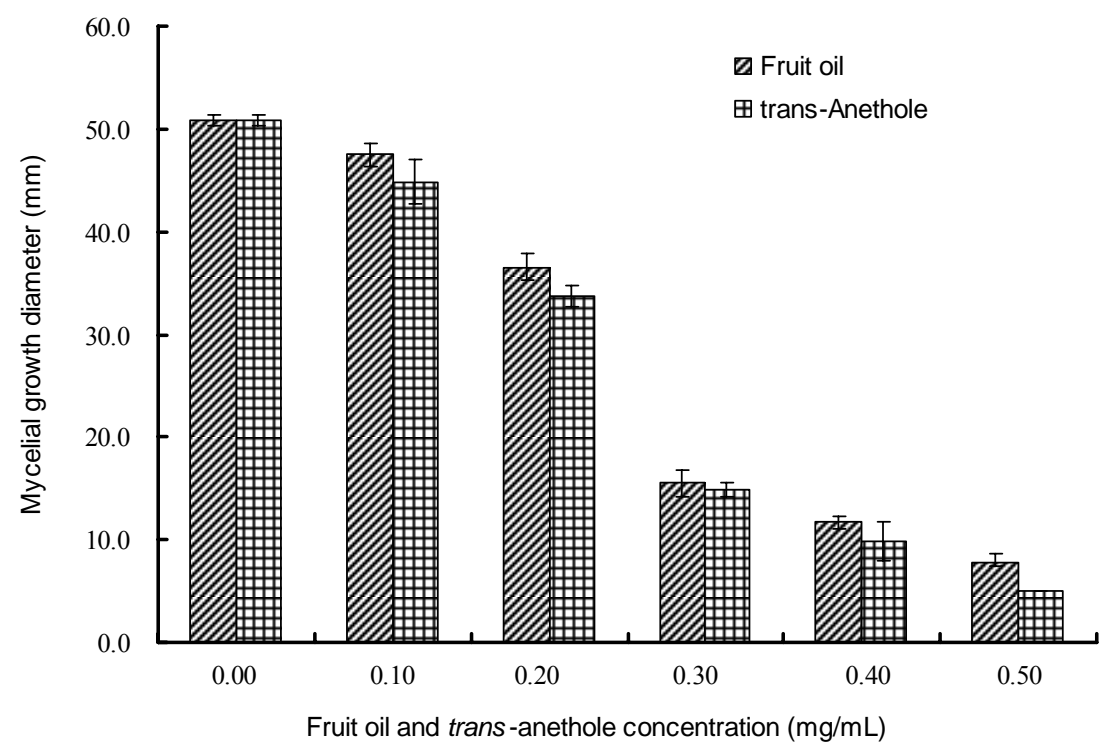


Six days after exposure, both I. verum essential oil and trans-anethole at concentration of $0.5 \mathrm{mg} / \mathrm{mL}$ in medium inhibited the growth of $B$. theobromae mycelia at the rate of $68.20 \%$ and $83.04 \%$, respectively (Figure 2). Their $\mathrm{IC}_{50}$ values were determined as $0.34 \mathrm{mg} / \mathrm{mL}$ $(Y=3.223 X+6.479, R=0.989)$ for the oil, and $0.27 \mathrm{mg} / \mathrm{mL}(Y=2.972 X+6.646, R=0.979)$ for trans-anethole, respectively. Both the vapor components in $I$. verum essential oil and trans-anethole displayed a slightly stronger inhibitory effect on P. aphanidermatum (Figure 1) than on B. theobromae (Figure 2) which was similar to the results obtained from the direct contact assay (Table 2). At all concentrations in medium, trans-anethole displayed a very similar inhibitory rate to the essential oil against the test fungi, which suggested again that trans-anethole was the main active component among the volatiles in $I$. verum essential oil. The use of essential oil volatiles has several benefits over direct application of the oils themselves (i.e. reduced toxicity, ease of application). This indicates that the volatiles of $I$. verum essential oil could be used as fumigants for plant disease management such as post-harvest disease control in fruit and vegetable preservation.

Figure 2. Effect of vapor components in I. verum fruit oil and trans-anethole on mycelial growth of $B$. theobromae by vapor contact assay.

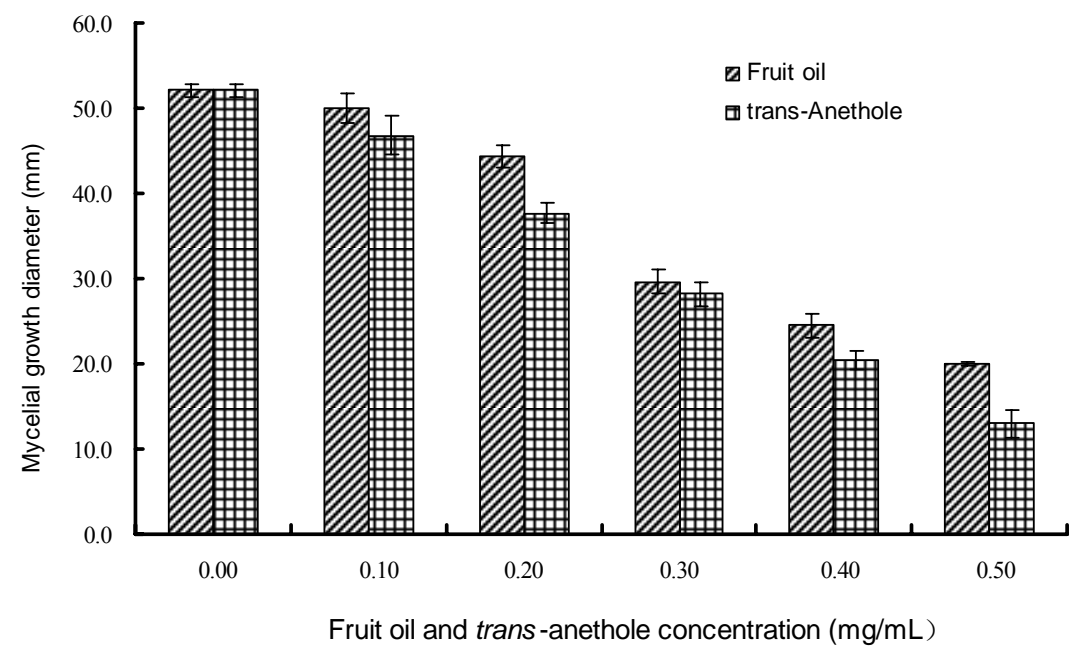

\subsection{Inhibitory activity on spore germination}

The inhibitory activity of the essential oil and trans-anethole on spore germination of $M$. oryzae was determined. The $\mathrm{IC}_{50}$ value of the oil against the spore germination was $0.32 \mathrm{mg} / \mathrm{mL}$ according to the regression equation $(Y=2.478 X+6.202, R=0.959$, where $Y$ is the inhibitory probit value, $X$ is concentration logarithm of the essential oil in spore suspension, and $R$ is correlation coefficient). The results obtained from the spore germination are shown in Figure 3. A negative control ran simultaneously in presence of acetone $(5 \%, \mathrm{v} / \mathrm{v})$ as that used in this study showed no inhibitory activity on spore germination, while the inhibitory effect of carbendazim (positive control) was $95.0 \%$ on spore germination at a concentration of $5.0 \mu \mathrm{g} / \mathrm{mL}$. There was a strong inhibition on spore germination of $M$. oryzae at different concentrations of $I$. verum essential oil with $92.50 \%$ inhibition at $1.0 \mathrm{mg} / \mathrm{mL}$ of the oil, $70.50 \%$ inhibition at $0.5 \mathrm{mg} / \mathrm{mL}$, and $58.40 \%$ at $0.4 \mathrm{mg} / \mathrm{mL}$, respectively. trans-Anethole also 
displayed an obvious inhibition on spore germination of $M$. oryzae, but its activity was a little weaker than that of the essential oil. It gave an $83.50 \%$ inhibition at $1.0 \mathrm{mg} / \mathrm{mL}, 60.23 \%$ inhibition at $0.5 \mathrm{mg} / \mathrm{mL}$, and $53.50 \%$ inhibition at $0.4 \mathrm{mg} / \mathrm{mL}$, respectively. It indicated that trans-anethole was the main component in the essential oil against spore germination of $M$. oryzae, though other minor components in the oil was also possible to contribute to the activity.

Figure 3. Inhibitory effect of $I$. verum fruit oil and trans-anethole on the spore germination of M. oryzae.

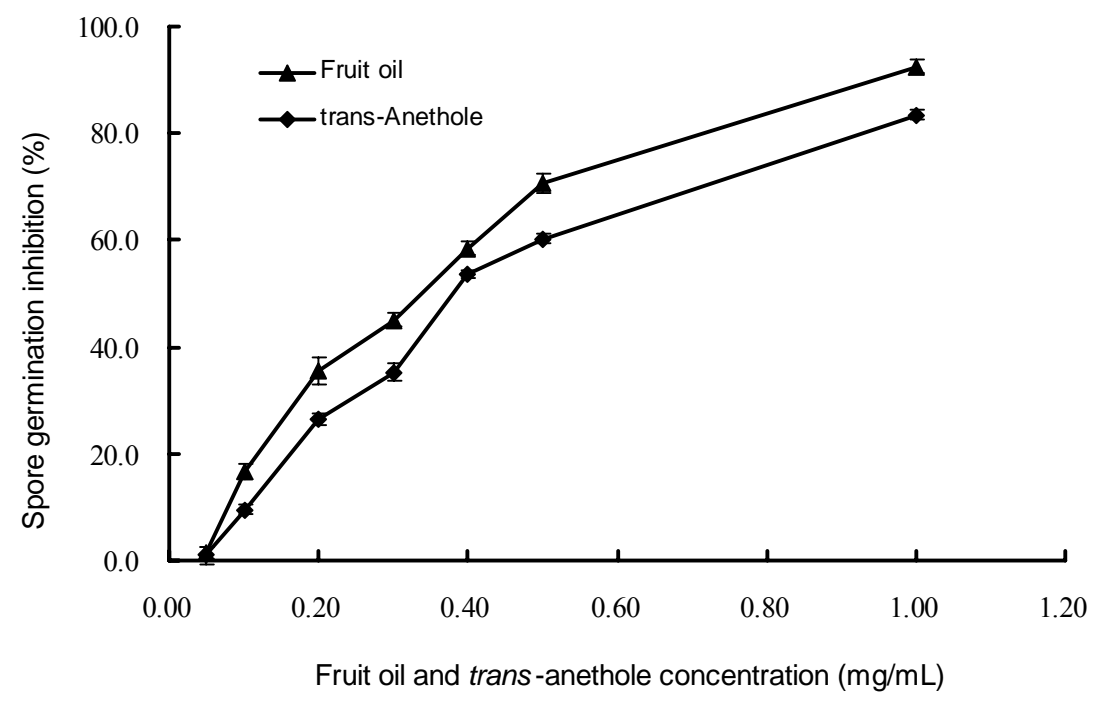

\section{Experimental}

\subsection{Plant material}

The dry fruits of I. verum were collected in September 2009 from Guangxi Province in the south of China, and were identified by Dr. Ye Wang of the Key Laboratory of Chemistry for Natural Products of Chinese Academy of Sciences in Guizhou Province of China. The voucher specimen (BSMPMI200909001) was deposited in the Herbarium of the Institute of Chinese Medicinal Materials, China Agricultural University. The fruits were stored at $4{ }^{\circ} \mathrm{C}$ before use.

\subsection{Preparation of the essential oil}

The fruits were broken into pieces, ground and then subjected to hydrodistillation in a Clevengertype apparatus. The distilled oil was extracted with diethyl ether, and then dried over anhydrous sodium sulfate and preserved in a sealed dark glass vials at $4{ }^{\circ} \mathrm{C}$ until required. Yield of the fruit essential oil was 7.48\% (w/w at dry weight basis). trans-Anethole (purity min. 98.0\%) was purchased from Tokyo Kasei Kogro Co., Ltd. (Japan). 


\subsection{Essential oil analysis}

The composition of the oil was determined by the use of analytical GC (FID) and GC/MS technique. The same column and analysis conditions were used for both GC and GC/MS. The total neutral essential oil from I. verum fruits was analyzed by an Agilent 6890N Network GC (gas chromatograph) system with an Agilent 5973 Network mass selective detector. The machine was equipped with an HP$5 \mathrm{MS}$ (mass spectroscopy) column $[30 \mathrm{~m} \times 0.25 \mathrm{~mm}$ (5\%-phenyl) -methylpolysiloxane capillary column, film thickness $\times 0.25 \mu \mathrm{m}$ ], a split-splitless injector at $250{ }^{\circ} \mathrm{C}$, and a flame ionization detector (FID) at $240{ }^{\circ} \mathrm{C}$. The oven temperature was programmed as follows: initial temperature $50{ }^{\circ} \mathrm{C}$ for $1 \mathrm{~min}$, increase $3{ }^{\circ} \mathrm{C} / \mathrm{min}$ up to $150{ }^{\circ} \mathrm{C}, 1 \mathrm{~min}$ at $150{ }^{\circ} \mathrm{C}$, and then increase $8{ }^{\circ} \mathrm{C} / \mathrm{min}$ up to $230{ }^{\circ} \mathrm{C}, 2 \mathrm{~min}$ at $230{ }^{\circ} \mathrm{C}$, finally, increase $20^{\circ} \mathrm{C} / \mathrm{min}$ up to $260{ }^{\circ} \mathrm{C}, 5 \mathrm{~min}$ at $260{ }^{\circ} \mathrm{C}$. The carrier gas was helium. The amount of sample injected was $1.0 \mu \mathrm{L}$ (split ratio 1:20) and the ionization energy was $70 \mathrm{eV}$. The components were identified by comparison of their mass spectra with those of NIST 2002 library data of the GC-MS system, as well as by comparison of their retention indices (RI) with literature data [17,21,33-39]. The relative amounts (RA) of individual component of the essential oil was expressed as percentages of the peak area relative to the total peak area. RI value of each component was determined relatively to the retention times (RT) of a series of $\mathrm{C}_{8}-\mathrm{C}_{40} n$-alkanes (Sigma) with linear interpolation on the HP-5MS column according to the Van den Dool approach [40].

\subsection{Test fungi}

Eleven plant pathogenic fungi, namely Alternaria solani, Bipolaris maydis, Botryodiplodia theobromae, Fusarium graminearum, Fusarium oxysporum f. sp. cucumerinum, Fusarium oxysporum f. sp. lycopersici, Fusarium oxysporum f. sp. vasinfectum, Magnaporthe oryzae, Pythium aphanidermatum, Rhizoctonia cerealis, and Rhizoctonia solani were kindly provided by the Department of Plant Pathology of China Agricultural University. They were maintained on potato dextrose agar (PDA) medium and then stored at $4{ }^{\circ} \mathrm{C}$. All the fungi were activated and then subcultured from 7 to 14 days in darkness at $25 \pm 2{ }^{\circ} \mathrm{C}$ by transferring from the stock cultures to PDA medium in Petri dishes before use.

\subsection{Evaluation of the antifungal activity}

\subsubsection{Determination of antifungal activity by direct contact assay}

Antifungal activity was studied by using an in vitro direct contact assay which was also called mycelial radial growth inhibition assay [41-44]. Briefly, the test sample (essential oil or trans-anethole) was mixed with PDA medium at $50{ }^{\circ} \mathrm{C}$ to obtain its final concentrations as $0.050 \mathrm{mg} / \mathrm{mL}$, $0.080 \mathrm{mg} / \mathrm{mL}, 0.10 \mathrm{mg} / \mathrm{mL}, 0.15 \mathrm{mg} / \mathrm{mL}, 0.20 \mathrm{mg} / \mathrm{mL}, 0.25 \mathrm{mg} / \mathrm{mL}$ and $0.30 \mathrm{mg} / \mathrm{mL}$, respectively. Then $10 \mathrm{~mL}$ of PDA medium was poured into a 6-cm diameter Petri dish before solidification. Discs (5-mm diameter) of the mycelial plugs from the edge of cultured fungal colony were cut and placed mycelial surface down on the centre of dishes. Three replicates were used for each treatment. All plates were then cultivated in the dark at $25 \pm 2{ }^{\circ} \mathrm{C}$. Mycelial diameter was measured when the hyphae of the control extended to the edge of dishes. The dishes without sample in PDA medium were used as 
the negative controls. Procymidone (Aldrich) at $5.0 \mu \mathrm{g} / \mathrm{mL}$ in medium was used as positive control for P. aphanidermatum test, and carbendazim (Aldrich) at $5.0 \mu \mathrm{g} / \mathrm{mL}$ in medium was used as positive control for the other fungal test. The percentage (\%) of mycelial growth inhibition was determined as $\left[\left(M_{\mathrm{c}}-M_{\mathrm{t}}\right) / M_{\mathrm{c}}\right] \times 100$, where $M_{\mathrm{c}}$ is an average of three replicates of mycelial growth diameter $(\mathrm{mm})$ increase of the negative controls, and $M_{\mathrm{t}}$ is an average of three replicates of mycelial growth diameter $(\mathrm{mm})$ increase of plates treated with the essential oil. The median inhibitory concentration $\left(\mathrm{IC}_{50}\right)$ against test fungi was calculated using the linear relation between the inhibitory probability and concentration logarithm according to methods outlined by Finney [45].

\subsubsection{Determination of antifungal activity by vapor contact assay}

The effects of either volatile components in the oil or trans-anethole were tested using $15-\mathrm{cm}$ diameter hermetical glass plate which contained two compartment 6-cm diameter Petri dishes, one contained PDA inoculated with either P. aphanidermatum or B. theobromae, and another contained $10 \mathrm{~mL}$ of PDA containing essential oil or trans-anethole at various concentrations of $0.20 \mathrm{mg} / \mathrm{mL}$, $0.50 \mathrm{mg} / \mathrm{mL}, 1.0 \mathrm{mg} / \mathrm{mL}, 2.0 \mathrm{mg} / \mathrm{mL}$ and $5.0 \mathrm{mg} / \mathrm{mL}$. PDA plate treated without the oil was used as the control. In this way, the fungi were not in direct contact with the sample and any effect on growth of the mycelia could be attributed to the volatile components. Three replicates were used for each treatment. All plates were then cultivated in the dark at $25 \pm 2{ }^{\circ} \mathrm{C}$ for 4 days for P. aphanidermatum or 6 days for $B$. theobromae. Mycelia diameter was measured when the diameter of the hyphae extended to the sides of dishes $[44,46]$. Mean growth measurements were calculated from three replicates of each test fungus. The percentage (\%) of the mycelia growth inhibition and $\mathrm{IC}_{50}$ values of the sample against the test fungi were calculated referring to the paragraph mentioned above.

\subsubsection{Determination of inhibitory activity on spore germination}

Rice blast fungus, Magnaporthe oryzae (strain P131) was maintained on oatmeal-tomato agar medium (oatmeal $30 \mathrm{~g} / \mathrm{L}$, tomato juice $150 \mathrm{~mL} / \mathrm{L}$, and agar $20 \mathrm{~g} / \mathrm{L}$ ) at $25^{\circ} \mathrm{C}$. The spores were prepared from 7-day-old cultures of $M$. oryzae, according to our previous reports $[47,48]$. The test sample (essential oil or trans-anethole) dissolved in $10 \%(\mathrm{v} / \mathrm{v})$ acetone solution with its different concentrations was mixed with equivalent volume of fungal spore suspension containing $2 \times 10^{6}$ spores per $\mathrm{mL}$. The mixture was then placed on separate concave glass slides. The final sample concentrations were $0.050 \mathrm{mg} / \mathrm{mL}, 0.10 \mathrm{mg} / \mathrm{mL}, 0.20 \mathrm{mg} / \mathrm{mL}, 0.30 \mathrm{mg} / \mathrm{mL}, 0.40 \mathrm{mg} / \mathrm{mL}, 0.50 \mathrm{mg} / \mathrm{mL}$ and $1.0 \mathrm{mg} / \mathrm{mL}$, respectively containing $5 \%(\mathrm{v} / \mathrm{v})$ acetone, together with two controls, i.e. $5 \%(\mathrm{v} / \mathrm{v})$ acetone as the negative control, and $5.0 \mu \mathrm{g} / \mathrm{mL}$ carbendazim as the positive control. Three replicates were used for each treatment. The slides containing spores were incubated in a moist chamber at $25 \pm 2{ }^{\circ} \mathrm{C}$ for $7 \mathrm{~h}$. Each slide was then observed under the microscope for spore germination status. About 300 spores were observed to detect spore germination. The percentage (\%) of the spore germination inhibition was determined as $\left[\left(G_{\mathrm{c}}-G_{\mathrm{t}}\right) / G_{\mathrm{c}}\right] \times 100$, where $G_{\mathrm{c}}$ is an average of three replicates of germinated spore numbers in the negative control, and $G_{\mathrm{t}}$ is an average of three replicates

of germinated numbers in the treated sets. The $\mathrm{IC}_{50}$ calculation for the spore germination inhibition was the same as that for mycelial growth inhibition described above. 


\section{Conclusions}

This study showed that the fruit essential oil of I. verum and trans-anethole had a wide inhibitory spectrum of activity against plant pathogenic fungi. The antifungal activity of the oil can be attributed by its high content of trans-anethole, which was confirmed as the main active component among the volatile compounds in the oil. Both the fruit essential oil and trans-anethole from I. verum could be developed as the natural fungicides (i.e. fumigants) for plant disease control in fruit and vegetable preservation.

\section{Acknowledgements}

This work was co-financed by the grants from the Special Fund for Agro-Scientific Research in the Public Interest of China (nyhyzx3-16 and 200903052), and the National Key Technology R\&D Program of China (2006BAD22B03 and 2008BADA5B03).

\section{References}

1. Pedras, M.S.C. Prospects for controlling plant fungal diseases: alternatives based on chemical ecology and biotechnology. Can. J. Chem. 2004, 82, 1329-1335.

2. Fletcher, J.; Bender, C.; Budowle, B.; Cobb, W.T.; Gold, S.E.; Ishimaru, C.A.; Luster, D.; Melcher, U.; Murch, R.; Scherm, H.; Seem, R.C.; Sherwood, J.L.; Sobral, B.W.; Tolin, S.A. Plant pathogen forensics: capabilities, needs, and recommendations. Microbiol. Mol. Biol. Rev. 2006, 70, 450-471.

3. Yamaguchi, I.; Fujimura, M. Recent topics on action mechanisms of fungicides. J. Pestic. Sci. 2005, 30, 67-74.

4. Margni, M.; Rossier, D.; Crettaz, P.; Jolliet, O. Life cycle impact assessment of pesticides on human health and ecosystems. Agr. Ecosyst. Environ. 2002, 93, 379-392.

5. Hadacek, F.; Greger, H. Testing of antifungal natural products: methodologies, comparability of results and assay choice. Phytochem. Anal. 2000, 11, 137-147.

6. Dixon, R.A. Natural products and plant disease resistance. Nature 2001, 411, 844-847.

7. Gimenez, C.; Cabrera, R.; Reina, M.; Gonalez-Coloma, A. Fungal endophytes and their role in plant protection. Curr. Org. Chem. 2007, 11, 707-720.

8. Yen, T.; Chang, H.; Hsieh, C.; Chang, S. Antifungal properties of ethanolic extract and its active compounds from Calocedrus macrolepis var. formosana (Florin) heartwood. Bioresource Technol. 2008, 99, 4871-4877.

9. Zhou, L.; Li, D.; Wang, J.; Liu, S.; Wu, J. Antibacterial phenolic compounds from the spines of Gleditsia sinensis Lam.. Nat. Prod. Res. 2007, 21, 283-291.

10. Zhou, L.; Li, D.; Jiang, W.; Qin, Z.; Zhao, S.; Qiu, M.; Wu, J. Two ellagic acid glycosides from Gleditsia sinensis Lam. with antifungal activity on Magnaporthe grisea. Nat. Prod. Res. 2007, 21, 303-309.

11. Lahlou, M. Essential oils and fragrance compounds: bioactivity and mechanisms of action. Flav. Fragr. J. 2004, 19, 159-165. 
12. Isman, M.B. Plant essential oils for pest and disease management. Crop Prot. 2000, 19, 603-608.

13. Tripathi, P.; Dubey, N.K. Exploitation of natural products as an alternative strategy to control postharvest fungal rotting of fruit and vegetables. Postharvest Biol. Technol. 2004, 32, 235-245.

14. Reddy, M.V.B.; Angers, P.; Gosselin, A.; Arul, J. Characterization and use of essential oil from Thymus vulgaris against Botrytis cinerea and Rhizopus stolonifer in strawberry fruits. Phytochemistry 1998, 47, 1515-1520.

15. Caccioni, D.R.L.; Guizzardi, M.; Biondi, D.M.; Renda, A.; Ruberto, G. Relationship between volatile components of Citrus fruits essential oil and antimicrobial action on Penicillium digitatum and Penicillium italicum. Int. J. Food Microbiol. 1998, 43, 73-79.

16. Tripathi, P.; Dubey, N.K.; Banerji, R.; Chansouria, J.P.N. Evaluation of some essential oils as botanical fungitoxicants in management of post-harvest rotting of citrus fruits. World J. Microbiol. Biotechnol. 2004, 20, 317-321.

17. Wang, Z.; Wang, L.; Li, T.; Zhou, X.; Ding, L.; Yu, Y.; Yu, A.; Zhang, H. Rapid analysis of the essential oils from dried Illicium verum Hook. f. and Zingiber officinale Rosc. by improved solvent-free microwave extraction with three types of microwave-absorption medium. Anal. Bioanal. Chem. 2006, 386, 1863-1868.

18. Bakkali, F.; Averbeck, S.; Averbeck, D.; Idaomar, M. Biological effects of essential oils - A review. Food Chem. Toxicol. 2008, 46, 446-475.

19. Okuyama, E.; Nakamura, T.; Yamazaki, M. Convulsants from star anise (Illicium verum Hook. f.). Chem. Pharm. Bull. 1993, 41, 1670-1671.

20. Lee, S.; Li, G.; Lee, K.S.; Jung, J.; Xu, M.; Seo, C.; Chang, H.; Kim, S.; Song, D.; Son, J. Preventive agents against sepsis and new phenylpropanoid glucosides from the fruits of Illicium verum. Planta Med. 2003, 69, 861-864.

21. Singh, G.; Maurya, S.; de Lampasona, M.P.; Catalan, C. Chemical constituents, antimicrobial investigations and antioxidative potential of volatile oil and acetone extract of star anise fruits. $J$. Sci. Food Agr. 2006, 86, 111-121.

22. Padmashree, A.; Roopa, N.; Semwal, A.D.; Sharma, G.K.; Agathian, G.; Bawa, A.S. Star-anise (Illicium verum) and black caraway (Carum nigrum) as natural antioxidants. Food Chem. 2007, 104, 59-66.

23. De, M.; De, A.K.; Sen, P.; Banerjee, A.B. Antimicrobial properties of star anise (Illicium verum). Phytother. Res. 2002, 16, 94-95.

24. Ravid, U.; Putievsky, E.; Katzir, I. Chiral GC analysis of enantiomerically pure (R)-(-)-linalyl acetate in some Lamiaceae, myrtle and petigrain oils. Flav. Fragr. J. 1994, 9, 275-276.

25. Gudzic, B.; Djokovic, D.; Vajs, V.; Palic, R.; Stojanovic, G. Composition and antimicrobial activity of the essential oil of Hypericum maculatum Crantz. Flav. Fragr. J. 2002, 17, 392-394.

26. Sajjadi, S.E.; Rahiminezhad, M.R.; Mehregan, I.; Poorassar, A. Constituents of essential oil of Hypericum dogonbadanicum Assadi. J. Essent. Oil Res. 2001, 13, 43-44.

27. Cheng, S.; Liu, J.; Tsai, K.; Chen, W.; Chang, S. Chemical composition and mosquito larvicidal activity of essential oils from leaves of different Cinnamomum osmophloeum provenances. J. Agr. Food Chem. 2004, 52, 4395-4400. 
28. Park, J.S.; Baek, H.H.; Bai, D.H.; Tae, K.; Lee, C.H. Antibacterial activity of fennel (Foeniculum vulgare Mill.) seed essential oil against the growth of Streptoccocus mutans. Food Sci. Biotechnol. 2004, 13, 581-585.

29. Orav, A.; Raal, A.; Arak, E. Essential oil composition of Pimpinella aisum L. fruits from various European countries. Nat. Prod. Res. 2008, 22, 227-232.

30. Toth, M.; Schmera, D.; Imrei, Z. Optimization of a chemical attractant for Epicometis (Tropinota) hirta Poda. Z. Naturforsch. C 2004, 59, 288-292.

31. Fujita, K.; Fujita, T.; Kubo, I. Anethole, a potential antimicrobial synergist, converts a fungistatic dodecanol to a fungicidal agent. Phytother. Res. 2007, 21, 47-51.

32. Knio, K.M.; Usta, J.; Dagher, S.; Zournajian, H.; Kreydivveh, S. Larvicidal activity of essential oils extracted from commonly used herbs in Lebanon against the seaside mosquito, Ochlerotatus caspius. Bioresource Technol. 2008, 99, 763-768.

33. Ravid, U.; Putievsky, E.; Katzir, I. Determination of the enantiomeric composition of $\alpha$-terpineol in essential oils. Flav. Fragr. J. 1995, 10, 281-284.

34. Adams, R.P. Identification of Essential Oils Components by Gas Chromatography/Quadrupole Mass Spectroscopy; Allured Publishing Corporation: Carol Stream, IL, USA, 2001.

35. Sacchetti, G.; Maietti, S.; Muzzoli, M.; Scaglianti, M.; Manfredini, S.; Radice, M.; Bruni, R. Comparative evaluation of 11 essential oils of different origin as functional antioxidants, antiradicals and antimicrobials in foods. Food Chem. 2005, 91, 621-632.

36. Sokovic, M.D.; Vukojevic, J.; Marin, P.D.; Brkic, D.D.; Vajs, V.; van Griensven, L.J.L.D. Chemical composition of essential oils of Thymus and Mentha species and their antifungal activities. Molecules 2009, 14, 238-249.

37. Martino, L.D.; Bruno, M.; Formisano, C.; Feo, V.D.; Napolitano, F.; Rosselli, S.; Senatore, F. Chemical composition and antimicrobial activity of the essential oils from two species of Thymus growing wild in southern Italy. Molecules 2009, 14, 4614-4624.

38. Mohsen, H.; Ali, F. Essential oil composition of Artemisia herba-alba from southern Tunisia. Molecules 2009, 14, 1585-1594.

39. Wang, J.; Liu, H.; Zhao, J.; Gao, H.; Zhou, L.; Liu, Z.; Chen, Y.; Sui, P. Antimicrobial and antioxidant activities of the root bark essential oil of Periploca sepium and its main component 2hydroxy-4-methoxybenzaldehyde. Molecules 2010, 15, 5807-5817.

40. Van den Dool, H.; Kratz, P.D. A generalization of the retention index system including linear temperature programmed gas-liquid partition chromatography. J. Chromatogr. 1963, 11, 463-471.

41. Quiroga, E.N.; Sampietro, A.R.; Vattuone, M.A. Screening antifungal activities of selected medicinal plants. J. Ethnopharmacol. 2001, 74, 89-96.

42. Cakir, A.; Kordali, S.; Zengin, H.; Izumi, S.; Hirata, T. Composition and antifungal activity of essential oils isolated from Hypericum hyssopifolium and Hypericum heterophyllum. Flav. Fragr. J. 2004, 19, 62-68.

43. Song, W.; Zhou, L.; Yang, C.; Cao, X.; Zhang, L.; Liu, X. Tomato Fusarium wilt and its chemical control strategies in a hydroponic system. Crop Prot. 2004, 23, 243-247.

44. Gong, Y.; Huang, Y.; Zhou, L.; Shi, X.; Guo, Z.; Wang, M.; Jiang, W. Chemical composition and antifungal activity of the fruit oil of Zanthoxylum bungeanum Maxim. (Rutaceae) from China. $J$. Essen. Oil Res. 2009, 21, 174-178. 
45. Finney, S. Probit Analysis; Cambridge University Press: Cambridge, UK, 1978.

46. Letessier, M.P.; Svoboda, K.P.; Walters, S.D.R. Antifungal activity of the essential oil of hyssop (Hyssopus offcinalis). J. Phytopathol. 2001, 149, 673-678.

47. Liu, H.; Wang, J.; Zhao, J.; Lu, S.; Wang, J.; Jiang, W.; Ma, Z.; Zhou, L. Isoquinoline alkaloids from Macleaya cordata active against plant microbial pathogens. Nat. Prod. Commun. 2009, 4, 1557-1560.

48. Wang, J.; Zhao, J.; Liu, H.; Zhou, L.; Liu, Z.; Wang, J.; Han, J.; Yu, Z.; Yang, F. Chemical analysis and biological activity of the essential oils of two valerianaceous species from China: Nardostachys chinensis and Valeriana officinalis. Molecules 2010, 15, 6411-6422.

Sample Availability: Samples of the compound and essential oil are available from the authors.

(C) 2010 by the authors; licensee MDPI, Basel, Switzerland. This article is an open access article distributed under the terms and conditions of the Creative Commons Attribution license (http://creativecommons.org/licenses/by/3.0/). 